\title{
Prevalence of spinal abnormalities in Chinook salmon smolt and influence of early rearing temperature and growth rates
}

\author{
J S Munday ${ }^{1}$ (D) M R Perrott ${ }^{1}$ | J E Symonds ${ }^{2}$ | S P Walker ${ }^{2}$ | M A Preece ${ }^{3}$ | \\ P S Davie ${ }^{1}$
}

${ }^{1}$ School of Veterinary Science, Massey University, Palmerston North, New Zealand ${ }^{2}$ Cawthron Institute, Nelson, New Zealand ${ }^{3}$ New Zealand King Salmon, Picton, New Zealand

\section{Correspondence}

John S Munday, School of Veterinary Science, Massey University, Palmerston North, New Zealand.

Email: j.munday@massey.ac.nz

Funding information

New Zealand Ministry of Primary Industries; Sustainable Farming Fund Project 13/003

\begin{abstract}
Spinal abnormalities can be detected at harvest in around $40 \%$ of farmed Chinook salmon in New Zealand. However, whether these abnormalities are present in smolt is unknown. Radiographs of 3,736 smolt were taken immediately prior to transfer to sea water and evaluated for fusions, compressions, vertical shifts, and lordosis, kyphosis and/or scoliosis (LKS). The survey included smolt from two different chilling strategies that had been graded into slow- or fast-growing fish. Overall, $4.34 \%$ of Chinook salmon smolt had at least one spinal abnormality, similar to the rates of reported in Atlantic salmon smolt. The rate of abnormality was significantly higher in faster-growing fish. Fusions were most common with $2.68 \%$ of smolt affected. Smolt subjected to longer chilling times had lower rates of fusions. Compressions and vertical shifts were both observed in $1.31 \%$ of smolt. Although LKS is the most common abnormality of harvested fish, LKS was detected in just five smolt. The results suggest that some fusions in harvest fish have developed at the time of seawater transfer while LKS develops late in the production cycle. Overall, spinal abnormalities are uncommon in Chinook salmon smolt and may be influenced by chilling times and growth rates.
\end{abstract}

KEYWORDS

Chinook, fusion, radiography, Salmon, smolt, spinal abnormality

\section{1 | INTRODUCTION}

Salmon farming is an important aquaculture industry in New Zealand worth around NZ\$130 million annually (http://www.salmon.org.nz). While multiple salmonid species have been introduced to New Zealand including rainbow trout (Oncorhynchus mykiss), Sockeye salmon (O. nerka), Atlantic salmon (Salmo salar) and brown trout (S. trutta) (McDowell, 1994), Chinook salmon (Oncorhynchus tshawytscha) is the only farmed salmonid. This is in contrast to other salmon farming industries where Atlantic salmon are predominantly farmed. Due to the dominance of Atlantic salmon in aquaculture throughout most of the world, much research has been performed investigating disorders of this species. In comparison, much less is known about disorders of farmed Chinook salmon.

Spinal abnormalities are a significant problem in farmed Atlantic salmon and can be detected at harvest in around $25 \%$ of fish by visual examination and palpation and in around $70 \%$ of fish by radiography (Fjelldal et al., 2012). Spinal abnormalities are important as they can result in slower growth with reduced harvest weights and reduced value of the fish (Boglione et al., 2013; Cobcroft \& Battaglene, 2013; Hansen, Fjelldal, Yurtseva, \& Berg, 2010; Haugarvoll, Bjerkas, Szabo, Satoh, \& Koppang, 2010; Silverstone \& Hammell, 2002). Spinal abnormalities in farmed Atlantic salmon have been subdivided into 20 different types that can be more broadly grouped into phenotypes (Witten, Gil-Martens, Huysseune, Takle, \& Hjelde, 2009). Of these phenotypes, fusions and compressions are most frequently reported in Atlantic salmon, and both are suspected to be the result of altered vertebral bone development (Fjelldal, Hansen, \& Berg, 2007; Witten, Gil-Martens, Hall, Huysseune, \& Obach, 2005; Witten, Obach, Huysseune, \& Baeverfjord, 2006; Ytteborg, Torgersen, Baeverfjord, \& Takle, 2012). While numerous factors including water conditions such as temperature and currents, nutritional 
factors, mineral or vitamin deficiencies (especially phosphorus and vitamin (), toxicities, genetics, trauma, vaccination, swim bladder dysfunction, weight at smoltification, growth rate of the fish and infectious agents have been reported to influence spinal abnormalities in Atlantic salmon (Boglione et al., 2013; Gil-Martens, 2010; Silverstone \& Hammell, 2002), this condition appears multifactorial, and few factors have been shown to reliably reproduce abnormalities in laboratory conditions (Boglione et al., 2013).

Studies in Atlantic salmon smolt prior to seawater transfer have reported rates of spinal abnormalities that are typically $4 \%-8 \%$ with abnormalities associated with numerous factors including growth rates, water temperature, diet, the location of the farm, vaccination, stripping period and the ploidy of the fish (Fjelldal et al., 2006; Fraser, Hansen, Fleming, \& Fjelldal, 2015; Sullivan, Guy, Roberts, \& Manchester, 2007a; Sullivan, Hammond, Roberts, \& Manchester, 2007b; Sullivan et al., 2007c; Ytteborg, Baeverfjord, Torgersen, Hjelde, \& Takle, 2010). As in harvest fish, the precise role of many of these factors in the development of spinal abnormalities is poorly understood. However, slower-growth rates and lower temperatures prior to seawater transfer have been consistently associated with lower rates of spinal abnormalities in Atlantic salmon smolt prior to seawater transfer (Fjelldal et al., 2006, 2012; Ytteborg et al., 2010).

Spinal abnormalities are also common in Chinook salmon with up to $40 \%$ of fish showing radiographic evidence of abnormality at harvest (Perrott et al., 2018). However, in contrast to Atlantic salmon (Boglione et al., 2013), vertical or horizontal curvature of the spine (lordosis, kyphosis and/or scoliosis (LKS)) is most common, with up to $30 \%$ of harvested fish affected. In comparison, radiographic evidence of fusions is seen in just $8 \%$ of harvested fish and compressions in $21 \%$ (Perrott et al., 2018). While the types of abnormalities that occur in Chinook salmon at harvest have been characterized, to the authors' knowledge, there have been no studies examining the rates and types of abnormalities present in commercially raised Chinook salmon smolt. Therefore, in this study, large numbers of Chinook salmon smolt were radiographed immediately prior to seawater transfer to determine the rate and types of abnormalities present. By identifying the abnormalities that are present in young fish, it could be determined whether the abnormalities that are observed in harvest fish are likely to be initiated prior to seawater transfer or develop later in the production cycle. In addition, smolt from different chilling strategies and with different growth rates were compared. If differences between these groups were identified, it is possible that manipulation of the water temperature or growth rates could be used to reduce the development of abnormalities in smolt.

\section{2 | MATERIALS AND METHODS}

All smolt examined in this study were sampled from the same hatchery, sourced from the same in-house breeding programme and from the same year class. This hatchery was selected because fish raised from this hatchery had been evaluated in studies of abnormalities in Chinook salmon at harvest (Perrott et al., 2018). Fertilized eggs were incubated at $10^{\circ} \mathrm{C}$ prior to hatching. After hatching, two different chilling strategies were used to achieve a year-round supply of fish to harvest. The strategy 1 (S1) fish were chilled at $10^{\circ} \mathrm{C}$ for 77 days while the $\mathrm{S} 2$ fish were chilled at $6.8^{\circ} \mathrm{C}$ for 127 days. After chilling, all fish were maintained at $12.4^{\circ} \mathrm{C}$ until transfer to sea water. Fish in both strategies were subdivided into slow-growing fish and fastgrowing fish by grading on weight when at approximately $15 \mathrm{~g}$ and then again when at approximately $50 \mathrm{~g}$. The slower-growing S1 fish (S1-S) were raised in freshwater for 263 days prior to seawater transfer, the faster-growing S1 fish (S1-F) were grown for 275 days, the slower-growing S2 fish (S2-S) for 320 days, and the faster-growing S2 fish (S2-F) for 348 days. The length of time that fish in each group were grown in freshwater was determined by farm management practices. Representative fish were randomly selected from each of the four groups and euthanatized by an overdose of AQUI-S (AQUI-S New Zealand Ltd, Lower Hutt, New Zealand) at the time of transfer to sea water. The fish were collected in groups of around 100 and weighed as a group. Growth rates were calculated using the age and weights of the fish. The fish were frozen and shipped to Massey University for radiographic evaluation.

For radiographic examination, fish were defrosted overnight, and a radiograph was taken of the whole vertebral column of each fish with a Phillips Bucky Diagnostics Ceiling System (Royal Philips, Amsterdam, the Netherlands) and a Canon CXDI-50G sensor (Canon Inc, Tokyo, Japan) $80 \mathrm{~cm}$ from source, set at $60 \mathrm{kV}, 3.2 \mathrm{mAs}$. Digital images were viewed on ClearCanvas vetstation (Synaptive Medical, Toronto, Canada) or as.jpg files using Adobe Photoshop CS6 (Adobe Systems, San Jose, California). Radiographs were examined for abnormalities in each of the four regions of the vertebral column that have previously been defined for Atlantic salmon (Kacem, Meunier, \& Baglinière, 1998). Vertebra was counted by identifying the vertebral body and counting caudally from the head. Region 1 consisted of vertebra 1 to vertebra 8, Region 2 vertebra 9 to vertebra 31 , region 3 vertebra 32 to vertebra 50 and region 4 vertebra 51 to vertebra $\sim 63$. Not all fish have the same number of vertebrae, and this variation was included in region 4 . The radiographs were evaluated for four abnormality phenotypes (Figure 1) including compressions and decreased intervertebral spaces (including Witten types 1 , 2, 3, 4, 5), fusions (Witten types 6, 7, 8), LKS (Witten types 14, 15, 16) and vertical displacement of the entire vertebra (vertical shifts, Witten type 17) (Witten et al., 2009). Abnormalities were only classified phenotypically and the precise Witten type of the compression, fusion or LKS was not determined. When an abnormality was identified, the affected region was noted. If a large fusion was present, the number of vertebra within the fusion was counted. If an abnormality extended across two regions then the abnormality was considered to be present in both vertebral regions. The severity of the abnormalities was not quantified. It is possible that freezing and thawing of the smolt could result in artefactual curving or straightening of the spine and therefore make a definitive diagnosis of LKS difficult. However, the authors have radiographed numerous previously frozen Chinook salmon and have found no evidence that freezing and thawing either causes or reduces spinal curvature of the fish. 
The rates of total abnormalities, fusions, compression, vertical shifts and LKS in each of the four management strategies were compared using ANOVA. The same statistical techniques were also used to detect differences in the region of the fish affected by abnormalities in fish in each of the four growth strategies. All statistical analyses were performed using IBM SPSS Statistics version 22 (IBM Corp, Armonk, New York) with a $p<.05$ considered significant.

\section{3 | RESULTS}

The study comprised 3736 smolt including 1518 S1-S, 996 S1-F, 755 S2-S and 467 S2-F smolt. The characteristics of the smolt are summarized in Table 1. At the time of transfer to sea water, the S1$\mathrm{S}$ and S1-F smolt had a mean weight of 57.7 and $80 \mathrm{~g}$, respectively. The S1-S fish had a mean growth rate of $0.22 \mathrm{~g} /$ day while the S1-F fish grew at $0.29 \mathrm{~g} /$ day. The S2 fish were transferred to sea water when they were around 70 days older than the S1 fish. The S2-S fish had a mean weight of $84.1 \mathrm{~g}$ and a mean growth rate of $0.26 \mathrm{~g} /$ day while the S2-F fish had a mean weight of $150.5 \mathrm{~g}$ and a mean growth rate of $0.43 \mathrm{~g} /$ day.

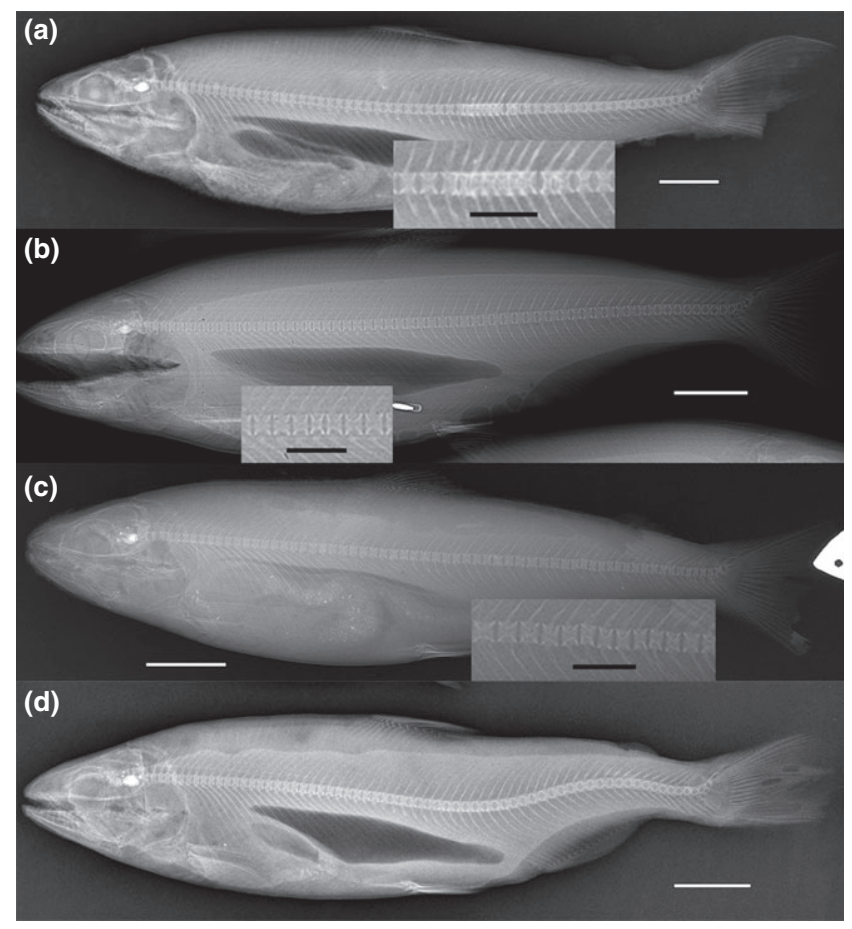

FIGURE 1 Radiographs of Chinook salmon smolt. 1a is a S1-S smolt showing two fusions including fusion of seven vertebrae (V43, V40) and two vertebrae (V41,42). The figure scale bar is $11 \mathrm{~mm}$ long, and the inset scale bar is $6.4 \mathrm{~mm}$ long. $1 \mathrm{~b}$ is a S1-S smolt showing compression of vertebra 19 and flattened cranial end of vertebra 20. The figure scale bar is $10.5 \mathrm{~mm}$ long, and the inset scale bar is $3.9 \mathrm{~mm}$ long. $1 \mathrm{c}$ is a S2-F smolt with multiple fusions (fusions V38,39; V41,42; V43,44) and vertical shift of V49 dorsally. The figure scale bar is $17 \mathrm{~mm}$ long, and the inset scale bar is $7 \mathrm{~mm}$ long. $1 \mathrm{~d}$ is a S2-S smolt showing spinal curvature in regions 3 and 4. The figure scale bar is $13.5 \mathrm{~mm}$ long
Overall, 162 (4.34\%) smolt had at least one spinal abnormality (Table 2, Figure 2). Rates were significantly lower in the S1-S $(3.56 \%)$ than in the S1-F fish $(6.12 \%, p=.002)$ and lower in the S2$\mathrm{S}$ fish (3.18\%) than the S2-F fish (4.93\%. $p=.046)$. The most common abnormality observed within the smolt was vertebral fusions with $100(2.68 \%)$ of the smolt affected. Fusions were significantly less common in the S2-S and S2-F smolt (1.06\% and $1.28 \%$, respectively) than in the S1-S and S1-F smolt $(2.96 \%$ and $4.11 \%$, respectively; $p<.01$ ). Overall $1.31 \%$ of smolt had vertebral compressions. Compressions were less common in the S1-S $(0.99 \%)$ than the S1-F smolt (1.91\%; $p=.04)$, but no significant difference was detected between the S2-S and S2-F smolt $(p=.07)$. Vertical shifts were observed in $1.31 \%$ of the smolt. Fewer vertical shifts were observed in S1-S (0.59\%) than S1-F smolt $(2.01 \% ; p=.001)$, but there were no significant differences between S2-S and S2-F smolt $(p=.09)$. Only five $(0.13 \%)$ smolt had LKS.

Of the 162 fish that had spinal abnormalities, 34 fish had multiple abnormality types with 18 having fusions and compressions; six having fusions, compressions and vertical shifts; five having vertical shifts and compressions; four having fusions and vertical shifts; and one having LKS, compressions and vertical shifts.

Spinal abnormalities were more frequent in regions 1,2 and 3 than in region 4 in all groups except the S1-F smolt that had similar rates of abnormality within all spinal regions (Table 3 ). A significantly higher rate of R3 abnormalities was seen in the S1-F fish than the S1-S fish ( $p=.04)$. A higher rate of abnormalities was also seen in R4 in the S1-F fish than in R4 of S1-S and R4 of S2-S $(p<.01)$. There were no significant differences in the distribution of abnormalities within the spinal regions between the S2-S and S2-F smolt. Table 4 contains a summary of which abnormalities were more common in each region.

\section{4 | DISCUSSION}

The overall rate of spinal abnormality in the Chinook salmon smolt was $4.3 \%$. This rate is similar to the $4 \%-8 \%$ generally reported for Atlantic salmon smolts (Fjelldal et al., 2006; Fraser et al., 2015;

TABLE 1 Summary of the characteristics of the smolt included in the study

\begin{tabular}{|llllll} 
Strategies & $\begin{array}{l}\text { Number } \\
\text { of fish }\end{array}$ & $\begin{array}{l}\text { Chilling after } \\
\text { hatching }\end{array}$ & $\begin{array}{l}\text { Age at } \\
\text { sampling } \\
\text { (days) }\end{array}$ & $\begin{array}{l}\text { Mean } \\
\text { weight } \\
\text { (g) }\end{array}$ & $\begin{array}{l}\text { Mean } \\
\text { growth } \\
\text { rate } \\
\text { (g/day) }\end{array}$ \\
\hline S1-S & 1518 & $\begin{array}{l}77 \text { days at } \\
10^{\circ} \mathrm{C}\end{array}$ & 263 & 57.7 & 0.22 \\
\hline S1-F & 996 & $\begin{array}{c}77 \text { days at } \\
10^{\circ} \mathrm{C}\end{array}$ & 275 & 80 & 0.29 \\
\hline S2-S & 755 & $\begin{array}{c}127 \text { days at } \\
6.8^{\circ} \mathrm{C} \\
127 \text { days at } \\
6.8^{\circ} \mathrm{C}\end{array}$ & 320 & 84.1 & 0.26 \\
\hline S2-F & 467 & 348 & 150.5 & 0.43 \\
\hline
\end{tabular}


TABLE 2 Summary of the spinal abnormalities detected by radiography in Chinook salmon smolt from four different strategies

\begin{tabular}{|c|c|c|c|c|c|}
\hline Strategies & $\begin{array}{l}\text { Fish with } \\
\text { fusions (\%) }\end{array}$ & $\begin{array}{l}\text { Fish with } \\
\text { compression (\%) }\end{array}$ & $\begin{array}{l}\text { Fish with } \\
\text { vertical shift (\%) }\end{array}$ & $\begin{array}{l}\text { Fish with } \\
\text { LKS (\%) }\end{array}$ & $\begin{array}{l}\text { Fish with any } \\
\text { abnormality (\%) }\end{array}$ \\
\hline S1-S & $45^{a}(2.96)$ & $15^{\mathrm{a}}(0.99)$ & $9^{a}(0.59)$ & $1^{\mathrm{a}}(0.07)$ & $54^{\mathrm{ab}}(3.56)$ \\
\hline S2-S & $8^{b}(1.06)$ & $6^{\mathrm{a}}(0.8)$ & $9^{\mathrm{ab}}(1.19)$ & $4^{a}(0.53)$ & $24^{a}(3.18)$ \\
\hline$S 2-F$ & $6^{\mathrm{b}}(1.28)$ & $9^{a b}(1.93)$ & $11^{\mathrm{b}}(2.36)$ & $0^{a}(0)$ & $23^{b c}(4.93)$ \\
\hline
\end{tabular}

Numbers with a different letter are significantly different $(p<.05)$. LKS is lordosis, kyphosis, and/or scoliosis.

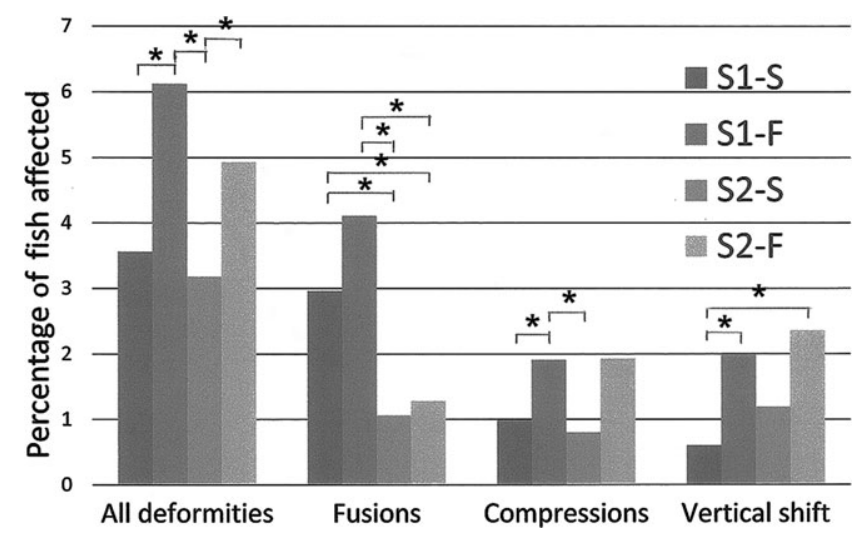

FIGURE 2 Graph showing the rates of spinal abnormalities observed in smolt that were raised with different chilling times and had different growth rates. Groups that are connected by bars indicated with an "*" had significant differences between the rates of abnormalities $(p<.05)$

TABLE 3 Summary of the vertebral regions in which spinal abnormalities were detected by radiography in Chinook salmon smolt from four strategies

\begin{tabular}{lllll} 
& $\begin{array}{l}\text { Fish with } \\
\text { R1 lesions } \\
\text { (\%) }\end{array}$ & $\begin{array}{l}\text { Fish with } \\
\text { R2 lesions } \\
(\%)\end{array}$ & $\begin{array}{l}\text { Fish with } \\
\text { R3 lesions } \\
(\%)\end{array}$ & $\begin{array}{l}\text { Fish with } \\
\text { R4 lesions } \\
\text { (\%) }\end{array}$ \\
\hline Strategies & $24(1.58)$ & $29(1.91)$ & $15^{\mathrm{a}}(0.98)$ & $6^{\mathrm{b}}(0.40)$ \\
\hline S1-F & $19(1.91)$ & $21(2.11)$ & $19^{\mathrm{a}}(1.91)$ & $17^{\mathrm{b}}(1.71)$ \\
\hline S2-S & $8(1.06)$ & $9(1.19)$ & $9(1.19)$ & $1^{\mathrm{b}}(0.13)$ \\
\hline S2-F & $6(1.28)$ & $8(1.71)$ & $8(1.71)$ & $4(0.85)$ \\
\hline All & $57(1.52)$ & $67(1.79)$ & $51(1.37)$ & $28(0.75)$ \\
\hline
\end{tabular}

andicates that S1-F fish had a significantly higher rate of abnormalities in the R3 region than the S1-S fish $(p<.05)$.

${ }^{\mathrm{b}}$ Indicates that S1-F fish had a significantly higher rate of abnormalities in the R4 region than the S1-S and the S2-S fish $(p<.05)$. No other significant differences were observed between the strategies.

Sullivan et al., 2007a, 2007b, 2007c; Elisabeth Ytteborg et al., 2012). As all the smolt in the present study were from the same hatchery, it is possible that Chinook smolt from different hatcheries could have different rates of abnormality. However, studies in Atlantic salmon have not shown a strong genetic basis for spinal deformities in smolt (Sullivan et al., 2007a), suggesting that environmental factors are more important. Only one hatchery was included in the present study because the majority of the salmon evaluated for abnormalities at harvest have been derived from smolt from this hatchery (Perrott et al., 2018). Therefore, by restricting our study to fish from this one hatchery, it was possible to determine which of the abnormalities observed in harvest fish were likely to have been present when the fish were smolt and which developed after saltwater transfer.

Overall, $2.7 \%$ of the smolt had fusions. Fusions are rare in harvest fish with radiographic evidence of fusions present in just $8 \%$ of harvested Chinook salmon (Perrott et al., 2018). Fused vertebra is not expected to separate as the animal grows with evidence from Atlantic salmon supporting either a stabilization or ongoing aggravated fusion pathway (Witten et al., 2006). Therefore, it appears that a significant proportion of the fusions that are observed in harvested fish may have already developed by the time that the smolt are transferred to sea water. While a proportion of fusions develop prior to transfer to sea water, these results also suggest that fusions continue to develop in Chinook salmon after seawater transfer. Fusions have also been reported to accumulate throughout the life of Atlantic salmon (Witten et al., 2006). However, in contrast to Chinook salmon, fusions are reported in $32 \%$ of Atlantic salmon 12 months after transfer to sea water (Witten et al., 2006), suggesting that fusions accumulate more rapidly after seawater transfer in Atlantic salmon than they do in Chinook salmon.

In the present study, $1.3 \%$ of Chinook salmon smolt had compressions at the time of transfer to sea water. As around $20 \%$ of harvested Chinook salmon have compressions (Perrott et al., 2018), the low rate seen in smolt suggests most compressions develop after transfer to sea water. This is in agreement with studies of Atlantic salmon that also suggest that most compressions occur late in the production cycle (Witten et al., 2005). Spinal compressions of Atlantic salmon have been proposed to be caused by increased mechanical load on the vertebra caused by the development of a large muscle mass (Witten et al., 2005). The much higher rates of compressions observed in harvested Chinook salmon than in Chinook salmon smolt support the hypothesis that the development of large muscles late in the life cycle predisposes them to the development of compressions.

Vertical shifts were detected in the Chinook salmon smolt at the same rate as compressions. However, vertical shifts remain rare in Chinook salmon and are detectable in less than $5 \%$ of fish at harvest (Perrott et al., 2018). Therefore, the detection of vertical shifts in $1.3 \%$ of smolt suggests that a significant proportion of vertical shifts develops prior to transfer to sea water. Vertical shifts, similarly to fusions, may accumulate slowly throughout the life of Chinook 
TABLE 4 Summary of the distribution within the vertebral regions of the detected spinal deformities in Chinook salmon smolt. LKS is lordosis, kyphosis and/or scoliosis

\begin{tabular}{|c|c|c|c|c|c|c|c|c|c|c|c|c|c|c|c|c|}
\hline Deformity phenotypes & \multicolumn{4}{|c|}{ LKS } & \multicolumn{4}{|c|}{ Fusion } & \multicolumn{4}{|c|}{ Compression } & \multicolumn{4}{|c|}{ Vertical shift } \\
\hline Number of smolt (\%) & \multicolumn{4}{|c|}{$5(0.13)$} & \multicolumn{4}{|c|}{$100(2.68)$} & \multicolumn{4}{|c|}{$49(1.31)$} & \multicolumn{4}{|c|}{$49(1.31)$} \\
\hline Number of instances of deformity phenotype in each region & R1 & R2 & R3 & R4 & R1 & $\mathrm{R} 2$ & R3 & R4 & $\mathrm{R} 1$ & R2 & R3 & R4 & $\mathrm{R} 1$ & $\mathrm{R} 2$ & R3 & R4 \\
\hline
\end{tabular}

salmon. In Atlantic salmon, vertical shifts have been reported to be associated with the development of compressions (Witten et al., 2009). In the presently described smolt, only vertical shifts were seen in 37 of the 49 smolt with this abnormality suggesting that vertical shifts can develop independently of other spinal abnormalities in young Chinook salmon.

LKS is the most common abnormality type seen in farmed Chinook salmon at harvest and can be detected in up to $30 \%$ of fish (Perrott et al., 2018). LKS was only detected in five smolt in the present study with this abnormality detected in $0.13 \%$ of fish. The very low rate of LKS in smolt supports previous observations that LKS develops later in life. While the cause of LKS in Chinook salmon remains unresolved, it is associated with unilateral inflammation and fibrosis, suggesting that LKS could be caused by damage to the perivertebral soft tissues by a process that is restricted to fish close to the end of the production cycle (Munday et al., 2016). Interestingly, although LKS has also been reported in other farmed fish species, especially European sea bass (Dicentrarchus labrax), gilthead seabream (Sparus aurata) and Atlantic cod (Gadus morhua); (Andrades, Becerra, \& Fernández-Llebrez, 1996; Boglione et al., 2013; Chatain, 1994), LKS in these fish species is observed early in life suggesting that LKS in Chinook salmon develops due to different mechanisms.

Four production strategies were compared in the present study. Our results suggest smolt that had grown at different rates had different rates of spinal abnormalities with the faster-growing smolt within each chilling protocol having higher rates of abnormalities than the slower-growing smolt. This is in agreement with studies in Atlantic salmon that also report that higher growth rates from hatching to smoltification are associated with higher rates of abnormalities (Fjelldal et al., 2006, 2012; Ytteborg et al., 2010). Additionally, smolt that had been chilled for longer at lower temperatures had a reduced rate of vertebral fusions. This is also consistent with reports in Atlantic salmon that identified an association between reduced abnormalities and lower water temperatures early in life (Fjelldal et al., 2006; Ytteborg et al., 2010).

Within the smolt the only significant difference in the region of the spine affected was the higher rate of abnormalities seen in regions 3 and 4 of the S1-F smolt when compared to S1-S smolt and, for region 4, when compared to the S2-S smolt. The significantly higher rate of abnormalities in these regions could be related to the faster growth of these smolt. However, it should be noted that there was no similar increase in the rate of abnormalities observed in the S2-F smolt when compared to the S2-S smolt. The failure to detect differences between the S2-F and the S2-S smolt could indicate that prolonged chilling could counteract the effect of faster growth in the development of abnormalities in regions 3 and 4. However, due to the lack of consistently increased abnormalities in regions 3 and 4 in the faster-growing fish of both strategies, additional studies are necessary to confirm these initial findings.

In conclusion, this is the first time that commercially raised Chinook salmon smolt have been evaluated for the presence of spinal abnormalities at the time of transfer to sea water. These results suggest that spinal abnormalities in farmed Chinook salmon smolt develop at a similar rate to that typically observed in Atlantic salmon smolt. Fusions were most frequent, and the results suggest that a significant proportion of fusions observed in harvested Chinook salmon developed prior to seawater transfer. Compressions and LKS were rare in the smolt suggesting these predominantly develop after seawater transfer. Fish with faster-growth rates developed a higher overall rate of abnormalities while fish that had a shorter chilling period post-hatching had higher rates of fusions. This suggests it may be possible to reduce spinal abnormalities in Chinook salmon smolt by optimization of chilling times and early growth rates of the fish.

\section{ACKNOWLEDGEMENTS}

We would like to acknowledge the New Zealand Ministry of Primary Industries for financial support (Sustainable Farming Fund Project 13/003: Reducing malformations in farmed King salmon). We thank the staff of the radiography section of the School of Veterinary Science for assistance with radiography and Mr Ty Mirko for assistance with scoring radiographs.

\section{ORCID}

\section{J S Munday (iD http://orcid.org/0000-0002-4769-5247 \\ P S Davie (iD http://orcid.org/0000-0002-5394-7519}

\section{REFERENCES}

Andrades, J. A., Becerra, J., \& Fernández-Llebrez, P. (1996). Skeletal deformities in larval, juvenile and adult stages of cultured gilthead sea bream (Sparus aurata L.). Aquaculture, 141(1), 1-11. https://doi. org/10.1016/0044-8486(95)01226-5

Boglione, C., Gisbert, E., Gavaia, P., Witten, E. P., Moren, M., Fontagné, S., \& Koumoundouros, G. (2013). Skeletal anomalies in reared European fish larvae and juveniles. Part 2: main typologies, occurrences 
and causative factors. Reviews in Aquaculture, 5, S121-S167. https://doi.org/10.1111/raq.12016

Chatain, B. (1994). Abnormal swimbladder development and lordosis in sea bass (Dicentrarchus labrax) and sea bream (Sparus auratus). Aquaculture, 119(4), 371-379. https://doi.org/10.1016/0044-8486(94) 90301-8

Cobcroft, J. M., \& Battaglene, S. C. (2013). Skeletal malformations in Australian marine finfish hatcheries. Aquaculture, 396-399, 51-58. https://doi.org/10.1016/j.aquaculture.2013.02.027

Fjelldal, P. G., Hansen, T. J., \& Berg, A. E. (2007). A radiological study on the development of vertebral deformities in cultured Atlantic salmon (Salmo salar L.). Aquaculture, 273(4), 721-728. https://doi.org/10. 1016/j.aquaculture.2007.07.009

Fjelldal, P. G., Hansen, T., Breck, O., Ørnsrud, R., Lock, E. J., Waagbø, R., \& Witten, E. P. (2012). Vertebral deformities in farmed Atlantic salmon (Salmo salar L.) - etiology and pathology. Journal of Applied Ichthyology, 28(3), 433-440. https://doi.org/10.1111/j.1439-0426. 2012.01980.x

Fjelldal, P. G., Lock, E. J., Grotmol, S., Totland, G. K., Nordgarden, U., Flik, G., \& Hansen, T. (2006). Impact of smolt production strategy on vertebral growth and mineralisation during smoltification and the early seawater phase in Atlantic salmon (Salmo salar, L.). Aquaculture, 261 (2), 715-728. https://doi.org/10.1016/j.aquaculture.2006.08.008

Fraser, T. W. K., Hansen, T., Fleming, M. S., \& Fjelldal, P. G. (2015). The prevalence of vertebral deformities is increased with higher egg incubation temperatures and triploidy in Atlantic salmon Salmo salar L. Journal of Fish Diseases, 38(1), 75-89. https://doi.org/10.1111/jfd. 12206

Gil-Martens, L. (2010). Inflammation as a potential risk factor for spinal deformities in farmed Atlantic salmon (Salmo salar L.). Journal of Applied Ichthyology, 26(2), 350-354. https://doi.org/10.1111/j.14390426.2010.01433.x

Hansen, T., Fjelldal, P. G., Yurtseva, A., \& Berg, A. (2010). A possible relation between growth and number of deformed vertebrae in Atlantic salmon (Salmo salar L.). Journal of Applied Ichthyology, 26(2), 355-359. https://doi.org/10.1111/j.1439-0426.2010.01434.x

Haugarvoll, E., Bjerkas, I., Szabo, N. J., Satoh, M., \& Koppang, E. O. (2010). Manifestations of systemic autoimmunity in vaccinated salmon. Vaccine, 28(31), 4961-4969. https://doi.org/10.1016/j.vaccine. 2010.05.032

Kacem, A., Meunier, F. J., \& Baglinière, J. L. (1998). A quantitative study of morphological and histological changes in the skeleton of Salmo salar during its anadromous migration. Journal of Fish Biology, 53, 1096-1109.

McDowell, R. M. (1994). The origins of New Zealand's Chinook salmon, Oncorhynchus tshawytscha. Marine Fisheries Review, 56, 1-7.

Munday, J. S., Perrott, M. R., Symonds, J. E., Walker, S. P., Lovett, B., Preece, M. A., \& Davie, P. S. (2016). Unilateral perivertebral fibrosis associated with lordosis, kyphosis and scoliosis (LKS) in farmed Chinook salmon in New Zealand. Diseases of Aquatic Organisms, 121(3), 211-221. https://doi.org/10.3354/dao03056

Perrott, M. R., Symonds, J. E., Walker, S. P., Hely, F. S., Wybourne, B., Preece, M. A., \& Davie, P. S. (2018). Spinal curvatures and onset of vertebral deformities in farmed Chinook salmon (Oncorhynchus tshawytscha) in New Zealand. Journal of Applied Ichthyology., In press. https://doi.org/10.1111/jai.13663

Silverstone, A. M., \& Hammell, L. (2002). Spinal deformities in farmed Atlantic salmon. The Canadian Veterinary Journal, 43(10), 782-784.

Sullivan, M., Guy, D. R., Roberts, R. J., \& Manchester, N. J. (2007a). The aetiology of spinal deformity in Atlantic salmon, Salmo salar L.: Influence of genetic factors on the frequency and severity in freshwater stages. Journal of Fish Diseases, 30(12), 753-758. https://doi.org/10. 1111/j.1365-2761.2007.00888.x

Sullivan, M., Hammond, G., Roberts, R. J., \& Manchester, N. J. (2007b). Spinal deformation in commercially cultured Atlantic salmon, Salmo salar L.: A clinical and radiological study. Journal of Fish Diseases, 30 (12), 745-752. https://doi.org/10.1111/j.1365-2761.2007.00889.x

Sullivan, M., Reid, S. W., Ternent, H., Manchester, N. J., Roberts, R. J., Stone, D. A., \& Hardy, R. W. (2007c). The aetiology of spinal deformity in Atlantic salmon, Salmo salar L.: Influence of different commercial diets on the incidence and severity of the preclinical condition in salmon parr under two contrasting husbandry regimes. Journal of Fish Diseases, 30(12), 759-767. https://doi.org/10.1111/j. 1365-2761.2007.00890.x

Witten, P. E., Gil-Martens, L., Hall, B. K., Huysseune, A., \& Obach, A. (2005). Compressed vertebrae in Atlantic salmon Salmo salar: Evidence for metaplastic chondrogenesis as a skeletogenic response late in ontogeny. Diseases of Aquatic Organisms, 64(3), 237-246. https://d oi.org/10.3354/dao064237

Witten, P. E., Gil-Martens, L., Huysseune, A., Takle, H., \& Hjelde, K. (2009). Towards a classification and an understanding of developmental relationships of vertebral body malformations in Atlantic salmon (Salmo salar L.). Aquaculture, 295(1-2), 6-14. https://doi.org/10. 1016/j.aquaculture.2009.06.037

Witten, P. E., Obach, A., Huysseune, A., \& Baeverfjord, G. (2006). Vertebrae fusion in Atlantic salmon (Salmo salar): Development, aggravation and pathways of containment. Aquaculture, 258(1-4), 164-172. https://doi.org/10.1016/j.aquaculture.2006.05.005

Ytteborg, E., Baeverfjord, G., Torgersen, J., Hjelde, K., \& Takle, H. (2010). Molecular pathology of vertebral deformities in hyperthermic Atlantic salmon (Salmo salar). BMC physiology, 10, 12. https://doi.org/10. 1186/1472-6793-10-12

Ytteborg, E., Torgersen, J., Baeverfjord, G., \& Takle, H. (2012). The Atlantic Salmon (Salmo salar) vertebra and cellular pathways to vertebral deformities. In E. Carvalho (Ed.), Health and Environment in Aquaculture (pp. 329-358). Rijeka, Croatia: InTech.

How to cite this article: Munday JS, Perrott MR, Symonds JE, Walker SP, Preece MA, Davie PS. Prevalence of spinal abnormalities in Chinook salmon smolt and influence of early rearing temperature and growth rates. J Fish Dis. 2018;41: 1111-1116. https://doi.org/10.1111/jfd.12804 
Prevalence of spinal abnormalities in

Chinook salmon smolt and influence of

early rearing temperature and growth rates

\author{
Munday, JS
}

2018-07

22/04/2023 - Downloaded from MASSEY RESEARCH ONLINE 